\title{
Methodology of the habitat classification of anthropogenic urban areas in Budapest (Hungary)
}

\author{
Attila Rigó ${ }^{1,2} \cdot$ Zoltán Barina ${ }^{2}$
}

Received: 20 February 2020 / Accepted: 9 April 2020 / Published online: 15 May 2020

(c) The Author(s) 2020

\begin{abstract}
The vast majority of floristical and coenological studies focus on the natural vegetation and its remnants in urban environments; however, there is an increasing interest in the systematic exploration of built environments. This survey of the inhabited areas of Budapest launched in 2018 applied a new and detailed methodology. The territorial units of the survey were street sections, where the presence of vascular plants was recorded in ecologically different habitats separately. We laid down the foundations to establish new habitat categories for the habitat classification and mapping of urban ecosystems using a different approach than the Hungarian habitat classification system (ÁNÉR). The method enables us to study the flora of urban ecosystems in detail. We established 18 urban habitat categories, surveyed more than 27,000 survey units and registered 647 spontaneously growing plant species in Budapest. Our survey evinced the spontaneous occurrence of 193 alien species in Budapest, 81 of them are data deficient, while 10 of them are new introductions in Hungary. 53.9\% of the aliens are cultivated frequently in Hungary.
\end{abstract}

Keywords Urban ecosystems $\cdot$ Anthropogenic habitats $\cdot$ Alien species $\cdot$ Introduction

\section{Introduction}

The invasion of plants is a major problem of recent biology, having serious negative impacts on natural habitats and human health (Early et al. 2016; Mazza et al. 2014; Rumlerová et al. 2016). The invasion of plants is preceded by a period which lasts from their introduction to their naturalisation in appropriate habitats (Blackburn et al. 2011). Urban ecosystems host a higher number of non-native species and can be the starting points of their expansion (Padayachee et al. 2017; von der Lippe et al. 2005). The dispersal and spreading of newly introduced species mostly depend on human activities (Ricotta et al. 2010). The extent of urbanisation nowadays is larger than ever in our history, more than half of the human population lives in cities now and the ratio of urban population is expected to grow even more in the next decades (United Nations 2019). Because of these facts,

Attila Rigó

rigo.attila@nhmus.hu

1 Department of Nature Conservation and Landscape Ecology, Szent István University, Gödöllő, Hungary

2 Department of Botany, Hungarian Natural History Museum, Budapest, Hungary the role of biologists and ecologists in studying the urban ecology and invasion biology has an increasing significance.

Urban ecosystems differ from natural and semi-natural habitats in many ways. The temperatures are higher (Mohajerani et al. 2017), air (Jorquera et al. 2019; Pascal et al. 2013) and soil pollution (Horváth et al. 2014; Li et al. 2018) are stronger than in the surrounding areas. Extremities and quick changes in the weather of urban areas are frequent, and the microclimate of urban areas is greatly influenced by city planning principles (Bourbia and Boucheriba 2010). Due to varying moisture, light and soil conditions, the surrounding natural environment, the different substrates, the orientation of the streets, the structure of the city, the level of human disturbance and the maintenance methods of the local government the occurring habitats in a city can be diverse (Rebele 1994), but the main determinant of the species composition of a city is the geographical location (Celesti Grapow and Blasi 1998). The habitats of an urban ecosystem show high heterogeneity both vertically and horizontally and change dynamically (Pickett et al. 2017). On account of the attributes mentioned above, supplemented by the cultural, commercial and touristic embeddedness of the given city, the biodiversity and ecosystem services of urban ecosystems can cover a very large scale (McPhearson et al. 2018). The 
study of the way of entry of alien plants to an urban ecosystem is difficult in the present, as historic data on the early occurrences of a species is necessary when investigating the origin of alien plant populations (Kowarik et al. 2013).

The number of systematic floristic and ecological studies of urban ecosystems increased at the end of the last century and the turn of the millennium, and an enormous amount of data gathered worldwide from urban habitats and numerous publications reached completion since then (e.g. Maslo 2014, 2015; Pyšek 1998).

In Hungary, there are examples for urban floristic research from the nineteenth century, e.g. Simonkai (1877) provides scattered data from the inner city of Budapest, but these researches were not systematic. In the twentieth century, Polgár (e.g. 1914) focused on the adventive flora of Győr (W Hungary), discovering the first occurrences of a high number of alien species in Hungary. The research of urban ecosystems is evolving in Hungary, an increasing number of papers, like the studies on the adventive woody flora of the Buda Castle (Czúcz 2005) and on the fern flora appearing on old built walls (Tamás et al. 2017), have been published in recent decades. There are many protected areas and (semi-) natural habitats in Budapest, and their floristic research has garnered a lot of attention recently (e.g. Nagy and Malatinszky 2019; Tóth and Papp 2012). The flora of Pécs (S Hungary) has been studied for a long period and is still being studied (Wirth et al. 2013, 2018).

An easily applicable habitat classification system (ÁNÉR) has been in use in Hungary for a long time (Fekete et al. 1997; Bölöni et al. 2007, 2011); however, its application in urban ecosytsems is very limited, as it treats all these areas under one or a few habitat classes. The purpose of ÁNÉR is to provide a habitat classification system for vegetation mapping in Hungary that is up-to-date, nationwide, coherent and covers the whole landscape, but ÁNÉR does not deal with micro-habitats below the usual vegetation mapping scale (1: 5000).

The majority of urban floristic studies focus on the species composition of urban areas and the comparison of urban floras (e.g. Pyšek 1998; Lososová et al. 2011), without considering ecological character, the distribution of habitats and high-resolution mapping. The floristic survey of Mostar (Bosnia-Herzegovina) was carried out in five different regions of the city and the main objective of this study was to enumerate the taxa of the urban ecosystem of Mostar (Maslo 2014, 2015). Lundholm and Marlin (2006) analysed the microhabitat preference and habitat origin of spontaneously occurring plant species in a university campus in Halifax (E Canada) in 11 different appointed habitat types. The work of Lososová et al. (2011) focused on the comparison of the urban floras of several Central European cities (including Budapest). These studies had integrated methodology using complex habitat categories and appointed study areas. Salinitro et al. (2018) assess the urban flora of Bologna (Italy) according to the various ecological niches distributed horizontally and vertically. The research of the urban and (semi-)natural flora of Podgorica (Montenegro) (Stešević et al. 2014) was very detailed and resulted in grid cell-based distribution maps of the found taxa and the very detailed typification and analysis of the urban habitats of Podgorica.

This paper presents a study on the urban flora of Budapest. The aim of our work was to (1) gain detailed and reliable reference datasets of the anthropogenic urban flora of Budapest (2) elaborate a method to comparably study the floristic composition of anthropogenic urban (micro-)habitats; (3) determine the habitat preference of the plant species in Budapest; (4) evaluate the taxa according to the latest Hungarian monographs; (5) investigate the way of entry of the species to the urban ecosystem of Budapest.

The hypotheses of our research were: (1) anthropogenic urban (micro-)habitats of Budapest are more diverse than can be described by the known habitat classification systems in Hungary; (2) the anthropogenic urban habitats of Budapest cannot be treated uniformly from an ecological point of view and the species have preferences among them; (3) the studied anthropogenic urban habitats of Budapest host a number of vascular plats not revealed by recent floristic studies in Hungary; (4) the rate of spontaneous occurrences of cultivated alien species (ornamentals, herbs, spices, fruits, vegetables and crops) is high in Budapest.

\section{Materials and methods}

The survey of urban habitats was carried out from September to November 2018. During this period, the data collecting lasted 65 days altogether. The study area covered all districts of Budapest (Fig. 1). Budapest is the capital of Hungary and is located in Central Hungary, between northern latitude $47.613437^{\circ}$ and $47.349269^{\circ}$, and eastern longitude $18.926381^{\circ}$ and $19.334538^{\circ}$. The altitude of the city varies from about $95 \mathrm{~m}$ to about $520 \mathrm{~m}$. Budapest is divided by the river Danube and surrounded by the Buda Mountains and the Pest plains.

The survey was limited to anthropogenic urban areas, natural and semi-natural habitats have been excluded from the research. The habitats of the following ÁNÉR categories (Bölöni et al. 2011) were studied: U1—Cities, areas with blocks of flats; U2-Suburbs and recreation areas; U3Villages (and village-like suburbs); U4-Yards, wastelands, dumping grounds.

The smallest possible, clearly identifiable units were investigated during the survey. The territorial units were street sections, public and domestic spaces. The applied street sections mean $50-150 \mathrm{~m}$ long sections of roads 


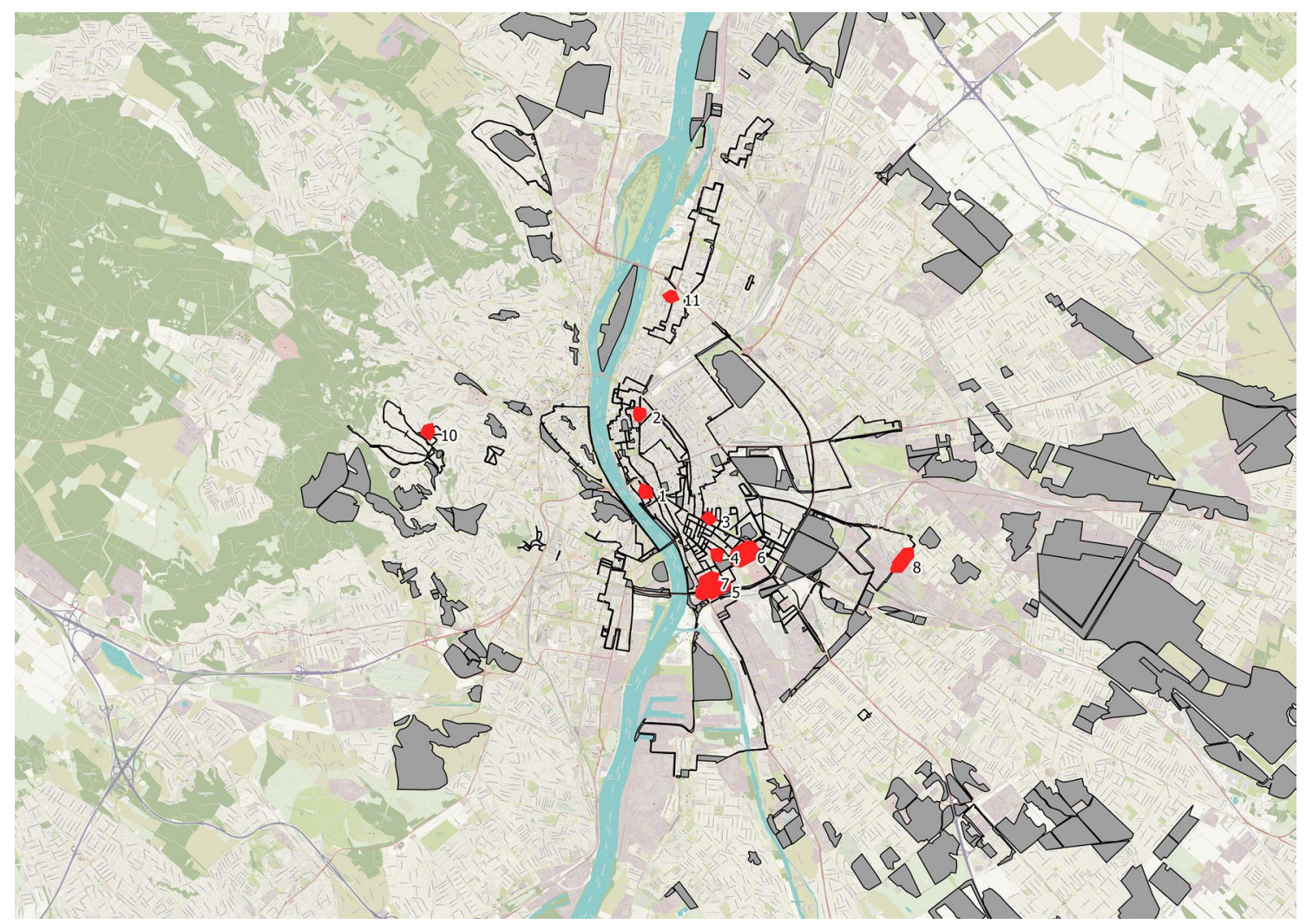

Fig. 1 Studied areas (grey) and occurrences of Thelypteris palustris (red) on rock walls in Budapest. 1: V. Veres Pálné u, 2: VI. Bajcsy Zsilinszky u, 3. VIII. Tömő u, 4. IX. Gát u, 5. IX. Máriássy u, 6. IX.

between crossing streets, blocks and squares (Fig. 2). Open public places (e.g. squares) are delimited by surrounding streets and blocks, while closed domestic areas (e.g. yards) are delimited by fences or walls (Fig. 2) and both cover an area of $100-1000 \mathrm{~m}^{2}$. The survey units (survey plots) were the distinguished habitats in the territorial units.

The survey attended to vascular plants, the nomenclature follows Király (2009), except for the ones that are missing from it, as in those cases we listed the authors. In the case of problematic taxonomic groups, aggregated names were used (e.g. Taraxacum officinale agg., Polygonum aviculare agg., etc.). A complete list of spontaneously occurring species has been recorded in every distinguished habitat within all surveyed units. The seedlings of cultivated plants were considered spontaneous occurrences. Planted individuals were recorded additionally to explore the local origin of spontaneously occurring specimens. In the case of descendants of cultivated species, the nearest occurrence of the planted (supposedly parent) individual
Szent István Hospital, 7. IX. Vágóhíd u, 8-9. X. Kőér u, 10. XII. Istenhegyi u, 11. XIII. Zsilip u. Made by using OpenStreetMap

was also recorded. During the preparation process, we aimed to distinguish as many (micro-) habitats as possible, after their revision the ones that were undistinguishable ecologically and in terms of use were merged.

The borders of the units, tracks and the occurrences of further noteworthy species (rare, protected or newly introduced species) were recorded with GPS devices. The collected specimens are stored in the herbarium of the Hungarian National History Museum (BP).

The terminology related to alien plants (introduced, casual, naturalised, and invasive) follows the categorisation of Richardson et al. (2000). The information on the status of alien plants in Hungary is gathered from Balogh et al. (2004). Our species list has been compared with the latest Hungarian monographs (Balogh et al. 2004; Király 2009; Bartha et al. 2015; University of Sopron 2018-) to test their frequency and novelty. Data managing, filtering and counting the relative frequency of species in habitats and habitat groups were done using MS Excel. 


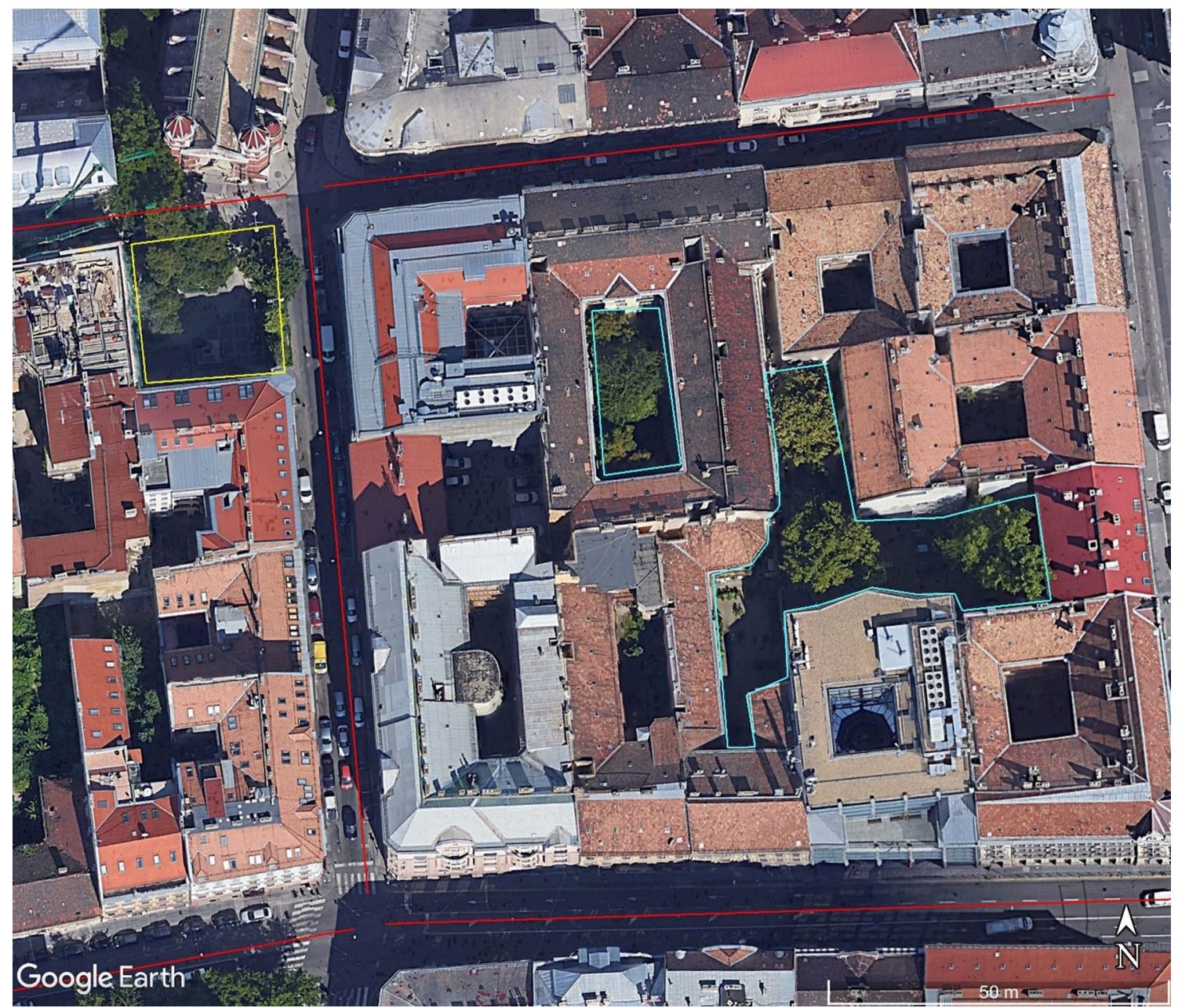

Fig. 2 Territorial units of the research: street sections (red), a square (yellow) and a closed yard (blue). Made by using Google Earth

\section{Results}

\section{Habitats}

Within the study area, 18 habitats were distinguished (Table 1). The most frequent habitats were: cracks, road verges, amenity grasslands, planting pits, urban hedges, flower boxes, courtyards and front gardens (Table 2). Based on the availability status and on the prevailing ecological factors and impacts, the habitats were grouped in 3 main groups: habitats of (1) road attached areas; (2) public areas and (3) domestic areas (Table 1). The habitats of road attached and public areas were usually more disturbed (trampled, mowed etc.) and polluted than the habitats of domestic areas. Walls, urban hedges, cracks and flower boxes occurred in all groups, so these habitats are treated as overlapping subcategories (Table 1).

Within the territory of Budapest, 2241 survey plots were studied, $90 \%$ of which were road attached and public areas, while domestic areas were less covered (Table 2). During the study, a total of 27105 plant occurrence records were collected which referred to 647 vascular plant taxa (Table 2). Altogether, the highest number of taxa were found in road verges, cracks and amenity grasslands, but regarding the single survey units, the most species-rich unit was an amenity grassland at Laczkovich street (Budapest District IX), with 96 species, while the average species number was highest in road slopes, ruderals and along railways and lowest in urban hedges (Fig. 3). The abundance of alien plants was highest in urban hedges and lowest in roadslopes, parks, amenity grasslands and road verges (Fig. 4). The number of occurrence records of rare (and partly protected) plants was highest on walls and in road slopes.

\section{Species pool}

According to our study, the top ten most frequent species are four alien and six native species. The most frequent species in the urban areas of Budapest are Polygonum aviculare agg., Taraxacum officinale agg. and Setaria viridis (Table 2). 
Table 1 Distinguished habitats with descriptions, grouped is habitat groups

\begin{tabular}{|c|c|c|}
\hline Habitat group & Subcategories (Abbreviation) & Description \\
\hline \multirow[t]{7}{*}{ Road attached areas } & Road verges $(\mathrm{Rv})$ & Lawns directly adjacent to the driveway (between the driveway and the pavement) \\
\hline & Railways (Ra) & Areas along railway tracks, tram rails, usually filled with stone rubble \\
\hline & Roadslopes (Rs) & Mostly dry, grassy slopes on banks, ditches and railway embankments \\
\hline & Safety islands (Si) & Paved islands in the middle of roads \\
\hline & Planting pits $(\mathrm{Pp})$ & $\begin{array}{l}\text { Pits for planted trees, often fenced off, covered with grid or plastic. These are } \\
\text { located in roadside lawns or in any paved urban areas. }\end{array}$ \\
\hline & Island beds (Ib) & Maintained, usually fenced off and/or elevated beds located on the street \\
\hline & Shrubby roadsides, alleys (Sh) & $\begin{array}{l}\text { Stands of spontaneously growing shrubs and trees along roads and in urban green } \\
\text { areas }\end{array}$ \\
\hline \multirow[t]{4}{*}{ Public areas } & Front gardens $(\mathrm{Fg})$ & $\begin{array}{l}\text { Council owned public areas in front of private houses, mostly maintained by the } \\
\text { residents. }\end{array}$ \\
\hline & Amenity grasslands $(\mathrm{Ag})$ & $\begin{array}{l}\text { Lawns that are not in the immediate vicinity of roads, mostly between the pavement } \\
\text { and residential buildings. }\end{array}$ \\
\hline & Parks $(\mathrm{Pa})$ & $\begin{array}{l}\text { Maintained and cultivated, public, green areas with mowed lawns and ornamental } \\
\text { plantings }\end{array}$ \\
\hline & Ruderals (Ru) & $\begin{array}{l}\text { Areas continuously exposed to disturbance, paved with gravel or any other material, } \\
\text { mostly in enclosed areas }\end{array}$ \\
\hline \multirow[t]{3}{*}{ Domestic areas } & Gardens $(\mathrm{Ga})$ & Private, fenced off, cultivated areas \\
\hline & Ground-plots (Pl) & Abandoned vacant plots and construction sites \\
\hline & Courtyards (Co) & Private, uncultivated, mostly paved areas \\
\hline \multirow[t]{4}{*}{ Overlapping subcategories } & Walls (Wa) & $\begin{array}{l}\text { Vertical surfaces of built walls (plants growing at the base of the walls belong to the } \\
\text { 'cracks' }(\mathrm{Cr})\end{array}$ \\
\hline & Urban hedges (Uh) & Shrubs planted in rows to enclose areas or for ornamental purposes. \\
\hline & Cracks $(\mathrm{Cr})$ & $\begin{array}{l}\text { Any pavement cracks on roads, paths, sidewalks, etc., and at the base of walls, } \\
\text { fences, etc. }\end{array}$ \\
\hline & Flower boxes $(\mathrm{Fb})$ & Flower boxes, pots and jars filled with soil, compost or planting mixes \\
\hline
\end{tabular}

Polygonum aviculare agg. colonises all habitats, but is less common in domestic areas (gardens, courtyards and plots) and urban hedges. Taraxacum officinale agg. and Setaria viridis show less habitat preference, therefore they are frequent in almost each habitats (except urban hedges). In general, most weeds prefer permanently disturbed places, like public areas, road attached areas and flower boxes, while trees, shrubs and woody climbers prefer urban hedges and domestic areas, where there is only moderate disturbance. Ferns bear an outstanding preference for walls and courtyards. One of our most remarkable observations was that Thelypteris palustris, a protected fern species in Hungary, occurred relatively abundantly on built walls in Budapest (Fig. 1) and it was found to be the 7th most frequent plant species on walls with 11 records.

We found 117 species exclusively in road attached habitats, all of them with a single or few known localities there (e.g. Astragalus glycyphyllos, Peucedanum alsaticum). Most of the widespread taxa are characteristic in road attached habitats and cracks, as Eleusine indica (with 689 records and $82.9 \%$ of them in road attached habitats and in cracks), Eragrostis minor (with 611 records and $81.9 \%$ of them in road attached habitats and in cracks), and Polygonum aviculare agg. (with 1172 records and $78.0 \%$ of them along roads and in cracks). On the other hand, 136 taxa avoid road attached habitats and have no known localities there (e.g. Ranunculus repens, Asplenium ruta-muraria).

Taxa preferring public areas have usually less than 20 known localities altogether (e.g. Hieracium pilosella, Thrincia nudicaulis), while some taxa found in public areas have only one single known locality (e.g. Leontodon autumnalis, Mentha longifolia). Taxa of natural habitats-as Asparagus officinalis, Campanula persicifolia, Carpinus betulus, Hieracium sabaudanum, Fragaria vesca, Vicia sepium, Astragalus onobrychis-occur exclusively in or near domestic areas (especially gardens). There are some exclusive subspontaneous occurrences of remnants or descendants of planted ornamentals-as Taxus baccata, Vinca major, Melissa officinalis - in or near gardens, in front gardens, courtyards, parks and flower boxes.

The survey resulted in the spontaneous occurrence of 81 taxa which are missing in Bartha et al. (2015) (Table 3). It means that we know nothing or our knowledge is incomplete on the distribution of these species in Hungary. Twenty-one taxa are missing even in the extended and updated online version of this work (University of Sopron 2018-), as a consequence of the lack of any records of them in the last 15 years in Hungary (Table 3). Twenty-one 
Table 2 Descriptive data and the rank of the 50 most frequent species in studied habitats

Habitats (Abbreviations)

\begin{tabular}{|c|c|c|c|c|c|c|c|c|c|c|c|c|c|c|c|c|c|c|c|}
\hline & Total & $\mathrm{Rv}$ & Rs & $\mathrm{Ra}$ & $\mathrm{Si}$ & $\mathrm{Pp}$ & $\mathrm{Ib}$ & Sh & $\mathrm{Fg}$ & $\mathrm{Ag}$ & $\mathrm{Pa}$ & $\mathrm{Ru}$ & $\mathrm{Ga}$ & $\mathrm{Pl}$ & Co & $\mathrm{Wa}$ & Uh & $\mathrm{Cr}$ & $\mathrm{Fb}$ \\
\hline Nr. of species & 647 & 363 & 172 & 147 & 45 & 132 & 37 & 40 & 209 & 309 & 157 & 165 & 201 & 136 & 230 & 146 & 114 & 362 & 186 \\
\hline Nr. of records & 27105 & 5065 & 482 & 435 & 69 & 890 & 57 & 67 & 1253 & 4098 & 608 & 401 & 950 & 422 & 1275 & 435 & 498 & 9305 & 804 \\
\hline $\begin{array}{l}\text { Studied survey } \\
\text { plots }\end{array}$ & 2241 & 265 & 16 & 18 & 4 & 157 & 6 & 7 & 104 & 188 & 37 & 16 & 90 & 24 & 113 & 73 & 135 & 969 & 119 \\
\hline Taxon name & \multicolumn{19}{|c|}{ Rank } \\
\hline \begin{tabular}{|} 
Polygonum \\
aviculare agg.
\end{tabular} & 1 & 1 & 27 & 30 & 1 & 1 & 2 & - & 9 & 1 & 2 & 31 & 41 & 15 & 58 & 9 & 60 & 1 & 18 \\
\hline \begin{tabular}{|l|} 
Taraxacum \\
officinale agg.
\end{tabular} & 2 & 2 & 4 & 30 & 6 & 2 & 2 & 8 & 1 & 2 & 1 & 16 & 2 & 6 & 5 & 9 & 60 & 2 & 2 \\
\hline Setaria viridis & 3 & 3 & 6 & 2 & 1 & 5 & 14 & - & 11 & 6 & 24 & 2 & 3 & 3 & 6 & 3 & 42 & 6 & 5 \\
\hline $\begin{array}{l}\text { Conyza } \\
\text { canadensis }\end{array}$ & 4 & 6 & 11 & 1 & 1 & 10 & 1 & - & 6 & 8 & 3 & 5 & 3 & 2 & 9 & 1 & 16 & 5 & 12 \\
\hline $\begin{array}{l}\text { Stellaria } \\
\text { media }\end{array}$ & 5 & 10 & 37 & 47 & - & 3 & 7 & 3 & 2 & 19 & 3 & 55 & 8 & 19 & 10 & 9 & 42 & 8 & 1 \\
\hline $\begin{array}{l}\text { Eleusine } \\
\text { indica }\end{array}$ & 6 & 9 & 63 & 91 & - & 8 & - & - & 15 & 17 & 24 & 31 & 112 & 43 & 84 & 43 & 60 & 3 & 43 \\
\hline $\begin{array}{l}\text { Sonchus } \\
\text { oleraceus }\end{array}$ & 7 & 16 & 11 & 7 & - & 7 & 14 & - & 4 & 23 & 18 & 20 & 16 & 6 & 13 & 4 & 16 & 7 & 4 \\
\hline $\begin{array}{l}\text { Chenopodium } \\
\text { album agg. }\end{array}$ & 8 & 4 & 16 & 10 & 20 & 5 & 2 & - & 3 & 9 & 10 & 1 & 11 & 3 & 18 & 17 & 30 & 12 & 7 \\
\hline $\begin{array}{l}\text { Eragrostis } \\
\text { minor }\end{array}$ & 9 & 34 & 63 & 21 & 6 & 23 & 14 & - & 34 & 28 & 88 & 20 & 82 & 84 & 72 & 28 & 22 & 4 & 10 \\
\hline $\begin{array}{l}\text { Ailanthus } \\
\text { altissima }\end{array}$ & 10 & 21 & 11 & 3 & 20 & 11 & 14 & 3 & 18 & 20 & 34 & 2 & 7 & 1 & 8 & 6 & 2 & 10 & 13 \\
\hline $\begin{array}{l}\text { Hypochoeris } \\
\text { radicata }\end{array}$ & 11 & 11 & 37 & 47 & 6 & 17 & - & - & 16 & 4 & 5 & 85 & 22 & 62 & 4 & 43 & 22 & 16 & 33 \\
\hline $\begin{array}{l}\text { Portulaca } \\
\text { oleracea agg. }\end{array}$ & 12 & 25 & 16 & 10 & 6 & 14 & 7 & - & 34 & 13 & 40 & 9 & 53 & 43 & 72 & 22 & 60 & 9 & 10 \\
\hline \begin{tabular}{|l} 
Plantago \\
lanceolata
\end{tabular} & 13 & 7 & 11 & 3 & 1 & 36 & - & - & 48 & 3 & 24 & 85 & 33 & 19 & 26 & 17 & - & 17 & 95 \\
\hline $\begin{array}{l}\text { Erigeron } \\
\text { annuus }\end{array}$ & 14 & 17 & 4 & 30 & 6 & 28 & - & - & 6 & 17 & 10 & 20 & 6 & 6 & 10 & 43 & 30 & 22 & 23 \\
\hline Ballota nigra & 15 & 15 & 16 & 47 & - & 29 & 14 & 8 & 10 & 27 & 15 & 6 & 11 & 15 & 1 & 12 & 30 & 31 & 15 \\
\hline $\begin{array}{l}\text { Celtis } \\
\text { occidentalis }\end{array}$ & 16 & 47 & 63 & 3 & - & 23 & 14 & - & 16 & 32 & 31 & 2 & 1 & 19 & 6 & 33 & 1 & 29 & 15 \\
\hline Poа аппиа & 17 & 44 & - & - & - & 4 & 14 & - & 29 & 60 & 40 & - & 41 & 43 & - & 43 & 42 & 11 & 5 \\
\hline $\begin{array}{l}\text { Digitaria } \\
\text { sanguinalis }\end{array}$ & 18 & 26 & 63 & 6 & 6 & 26 & 2 & - & 24 & 38 & 51 & 31 & 44 & 28 & 109 & 22 & 60 & 13 & 23 \\
\hline $\begin{array}{l}\text { Oxalis } \\
\text { corniculata }\end{array}$ & 19 & 62 & - & - & - & 17 & - & - & 5 & 47 & 18 & 55 & 11 & 84 & 26 & 28 & 42 & 15 & 3 \\
\hline $\begin{array}{l}\text { Plantago } \\
\text { major }\end{array}$ & 19 & 22 & - & - & - & 12 & - & - & 29 & 25 & 40 & 85 & 53 & 43 & 72 & 74 & - & 14 & 33 \\
\hline
\end{tabular}


Table 2 (continued)

\begin{tabular}{|c|c|c|c|c|c|c|c|c|c|c|c|c|c|c|c|c|c|c|c|}
\hline $\begin{array}{l}\text { Lolium } \\
\text { perenne }\end{array}$ & 21 & 7 & 63 & 64 & - & 22 & - & - & 29 & 11 & 7 & - & 70 & - & 36 & 43 & 60 & 30 & 37 \\
\hline Elymus repens & 22 & 13 & 3 & 64 & 20 & 15 & 14 & - & 14 & 16 & 18 & 9 & 25 & 11 & 10 & 33 & 10 & 41 & 18 \\
\hline \begin{tabular}{|l|} 
Erodium \\
cicutarium
\end{tabular} & 22 & 14 & 27 & 30 & 6 & 26 & - & - & 36 & 9 & 15 & 31 & 70 & 62 & 31 & 43 & 60 & 28 & 37 \\
\hline $\begin{array}{l}\text { Amaranthus } \\
\text { retroflexus }\end{array}$ & 24 & 18 & 27 & 21 & 20 & 9 & 7 & - & 19 & 21 & 29 & 7 & 44 & 19 & 41 & - & 42 & 23 & 37 \\
\hline $\begin{array}{l}\text { Convolvulus } \\
\text { arvensis }\end{array}$ & 24 & 19 & 37 & 16 & 1 & 17 & 14 & - & 22 & 14 & 18 & 9 & 25 & 6 & 29 & 28 & 22 & 33 & 18 \\
\hline $\begin{array}{l}\text { Achillea } \\
\text { millefolium }\end{array}$ & 26 & 5 & 2 & 64 & - & 47 & - & - & 40 & 7 & 5 & 55 & 33 & 43 & 29 & 22 & 60 & 42 & 95 \\
\hline $\begin{array}{l}\text { Cynodon } \\
\text { dactylon }\end{array}$ & 27 & 12 & 27 & 21 & 6 & 29 & - & - & 53 & 5 & 10 & 9 & 70 & 62 & 66 & 74 & 12 & 36 & 23 \\
\hline Viola odorata & 28 & 28 & 16 & 47 & - & 39 & - & 2 & 6 & 44 & 14 & 85 & 8 & 62 & 3 & 17 & 16 & 32 & 33 \\
\hline $\begin{array}{l}\text { Chelidonium } \\
\text { majus }\end{array}$ & 29 & 39 & 63 & 21 & - & 56 & - & 3 & 13 & 57 & 40 & 85 & 10 & 28 & 18 & 1 & 22 & 25 & 37 \\
\hline Oxalis dillenii & 30 & 37 & - & 91 & 20 & 33 & 7 & - & 19 & 38 & 40 & 55 & 16 & 19 & 25 & 22 & 60 & 27 & 8 \\
\hline Morus alba & 31 & 62 & - & 47 & - & 29 & 2 & - & 28 & 68 & 60 & 31 & 15 & 6 & 13 & 33 & 4 & 21 & 27 \\
\hline $\begin{array}{l}\text { Senecio } \\
\text { vulgaris }\end{array}$ & 32 & 44 & 95 & 21 & - & 17 & - & - & 29 & 57 & 31 & - & 44 & 62 & 49 & 43 & 30 & 18 & 8 \\
\hline $\begin{array}{l}\text { Amaranthus } \\
\text { deflexus }\end{array}$ & 33 & 43 & - & 64 & - & 12 & 7 & - & 12 & 53 & 40 & 55 & 70 & 43 & 72 & 43 & 42 & 19 & 53 \\
\hline Silene alba & 34 & 20 & 27 & 64 & 6 & 56 & - & 17 & 78 & 14 & 31 & 31 & 38 & 28 & 21 & 74 & - & 44 & 95 \\
\hline $\begin{array}{l}\text { Capsella } \\
\text { bursa-pastoris }\end{array}$ & 35 & 37 & - & 64 & - & 15 & 14 & - & 44 & 49 & 34 & - & 112 & 62 & 41 & 43 & 60 & 24 & 18 \\
\hline \begin{tabular}{|l} 
Solanum \\
nigrum
\end{tabular} & 36 & 39 & 63 & 10 & - & 23 & 14 & - & 19 & 49 & 29 & 7 & 38 & 11 & 31 & 43 & - & 34 & 23 \\
\hline Acer negundo & 37 & 62 & 37 & 7 & - & - & 14 & 17 & 40 & 60 & 88 & 9 & 22 & 11 & 18 & 22 & 3 & 34 & 64 \\
\hline $\begin{array}{l}\text { Trifolium } \\
\text { repens }\end{array}$ & 38 & 34 & 63 & - & - & 43 & - & - & 44 & 12 & 7 & 31 & 112 & 28 & 109 & - & - & 53 & 64 \\
\hline \begin{tabular}{|l|} 
Ambrosia \\
artemisiifolia
\end{tabular} & 39 & 28 & 16 & 16 & 20 & 43 & 14 & - & 53 & 26 & 34 & 9 & 38 & 11 & 66 & - & 60 & 51 & 53 \\
\hline \begin{tabular}{|l} 
Dactylis \\
glomerata
\end{tabular} & 39 & 27 & 6 & 30 & - & 43 & 7 & 3 & 61 & 28 & 18 & 55 & 25 & 28 & 31 & 43 & 30 & 59 & - \\
\hline Hedera helix & 41 & 56 & 27 & 64 & - & 39 & - & 1 & 26 & 101 & 34 & 85 & 3 & 84 & 2 & 33 & 7 & 103 & 27 \\
\hline $\begin{array}{l}\text { Medicago } \\
\text { sativa }\end{array}$ & 42 & 33 & 1 & 21 & 20 & 39 & - & - & 126 & 21 & 51 & 31 & 112 & 28 & 38 & 74 & - & 64 & - \\
\hline $\begin{array}{l}\text { Tribulus } \\
\text { terrestris }\end{array}$ & 43 & 24 & 37 & 47 & 6 & 47 & - & - & 91 & 28 & 60 & 31 & 112 & - & - & - & - & 38 & - \\
\hline Rumex spp. & 44 & 23 & 95 & 91 & - & 56 & - & - & 48 & 35 & 51 & - & 30 & 28 & 49 & 74 & 60 & 64 & 33 \\
\hline $\begin{array}{l}\text { Geranium } \\
\text { pusillum }\end{array}$ & 45 & 36 & - & - & - & 47 & - & - & 53 & 33 & 7 & - & 82 & - & 41 & - & - & 38 & 64 \\
\hline
\end{tabular}


Table 2 (continued)

\begin{tabular}{|l|c|c|c|c|c|c|c|c|c|c|c|c|c|c|c|c|c|c|c|}
\hline $\begin{array}{l}\text { Robinia } \\
\text { pseudoacacia }\end{array}$ & 46 & 50 & 48 & 21 & - & 47 & 14 & 8 & 36 & 55 & 51 & 16 & 16 & 43 & 17 & 74 & 8 & 58 & 95 \\
\hline $\begin{array}{l}\text { Artemisia } \\
\text { vulgaris }\end{array}$ & 47 & 30 & 16 & 30 & - & 56 & - & 17 & 61 & 52 & 40 & 55 & 44 & 5 & 31 & 43 & 22 & 55 & 64 \\
\hline $\begin{array}{l}\text { Cirsium } \\
\text { arvense }\end{array}$ & 48 & 50 & 48 & 64 & - & 29 & - & - & 24 & 62 & 40 & 20 & 33 & 43 & 41 & 74 & 15 & 55 & 13 \\
\hline $\begin{array}{l}\text { Euphorbia } \\
\text { maculata }\end{array}$ & 49 & 92 & 95 & 21 & 20 & 75 & - & - & 91 & 73 & 60 & 85 & - & 84 & 141 & 22 & - & 26 & 30 \\
\hline Malva pusilla & 50 & 30 & - & 91 & 20 & 75 & - & - & 40 & 28 & 24 & 85 & 53 & 62 & 58 & 74 & - & 68 & 64 \\
\hline
\end{tabular}

The numbers in the 'Rank' columns indicate that if the plants are sorted by frequency, what would be the given plant in the row; '-' indicates that the plant is absent from that habitat

taxa are completely missing even in the latest Hungarian flora monograph (Király 2009) and further 28 are mentioned there only as a cultivated or ornamental plant (Table 3). Twenty-two taxa are missing from the latest list of neophytes in Hungary (Balogh et al. 2004), and ten taxa are missing in all the latest Hungarian monographs (Table 3); therefore, these are considered here as new introductions in Hungary.

\section{Alien taxa}

Altogether $70.2 \%$ of the recorded taxa are native and $29.8 \%$ (193 species) are aliens. $61.3 \%$ of the alien taxa are casuals, $11.1 \%$ are naturalised, $21.6 \%$ are considered invasive in the natural and semi-natural habitats of Hungary and $6 \%$ of them are new introductions in Hungary (e.g. Artemisia verlotiorum) (Fig. 5).

One hundred four (53.9\%) of the alien species are cultivated or their fruits or seeds are sold and eaten in Budapest. Eighty-six of them are planted frequently as ornamentals (e.g. Brunnera macrophylla, Euonymus japonicus), while the rest are herbs (e.g. Salvia officinalis, Calendula officinalis), fruits (e.g. Armeniaca vulgaris, Persica vulgaris), vegetables (e.g. Solanum lycopersicon, Cucumis sativus) and crops (e.g. Zea mays, Triticum aestivum) that escaped from cultivation or derived from households. In the case of 38 species, the potential parent plants were found within the same survey units $0.5-60 \mathrm{~m}$ away from the escapees (Table 4), while in other cases no planted parent plants could be identified there, only much further away. The range of the dispersal of cultivated plants is usually not more than $10 \mathrm{~m}$.

Considering the ten newly introduced taxa (Table 3), eight of them are garden escapees, which are as follows: Begonia cf. cucullata Willd, Celosia argentea L. [mentioned in Király (2009) only as an ornamental], Euonymus japonicus
Thunb, Gazania rigens (L.) Gaertn, Nepeta $\times$ faasenii Bergmans ex Stearn, Saccharum ravennae (L.) L, Salix babylonica L. and Vitex agnus-castus L. On the other hand, Artemisia verlotiorum Lamotte and Eragrostis virescens J. Presl are not cultivated in gardens, so their presence may be the result of spontaneous propagation and/or unintentional introduction.

\section{Discussion}

Using small sampling units and ecologically well-distinguished habitats, it was possible to collect over 27,000 habitat-specific occurrence data in a short period of time. The majority of the found species occur at different frequencies in the studied habitats. Some recent studies also suggested that the use of small, ecologically well-defined habitat categories is important to monitor the distribution and habitat preference of plants and the selectiveness of habitats (Lundholm and Marlin 2006; Salinitro et al. 2018; Steševic et al. 2014). The purpose of the applied habitat classification, which is based on the ecological differences of the (micro-)habitats studied, is remarkably different from that of the only system used in the region (ÁNÉR, Bölöni et al. 2011), which is used primarily for site mapping, while our method is developed for a more detailed classification on ecological basis. This study managed to include domestic areas unevenly, which, according to Wirth et al. (2018) can significantly influence the species list in a grid-based, fullcoverage study. In this case, however, the focus is on the habitats and the habitat preference of species, so it has no significant importance. The low abundance of records from domestic areas is the clear consequence of their restricted availability. The majority of the species found in Budapest are connected to exact habitats or habitat groups, while 
120,00

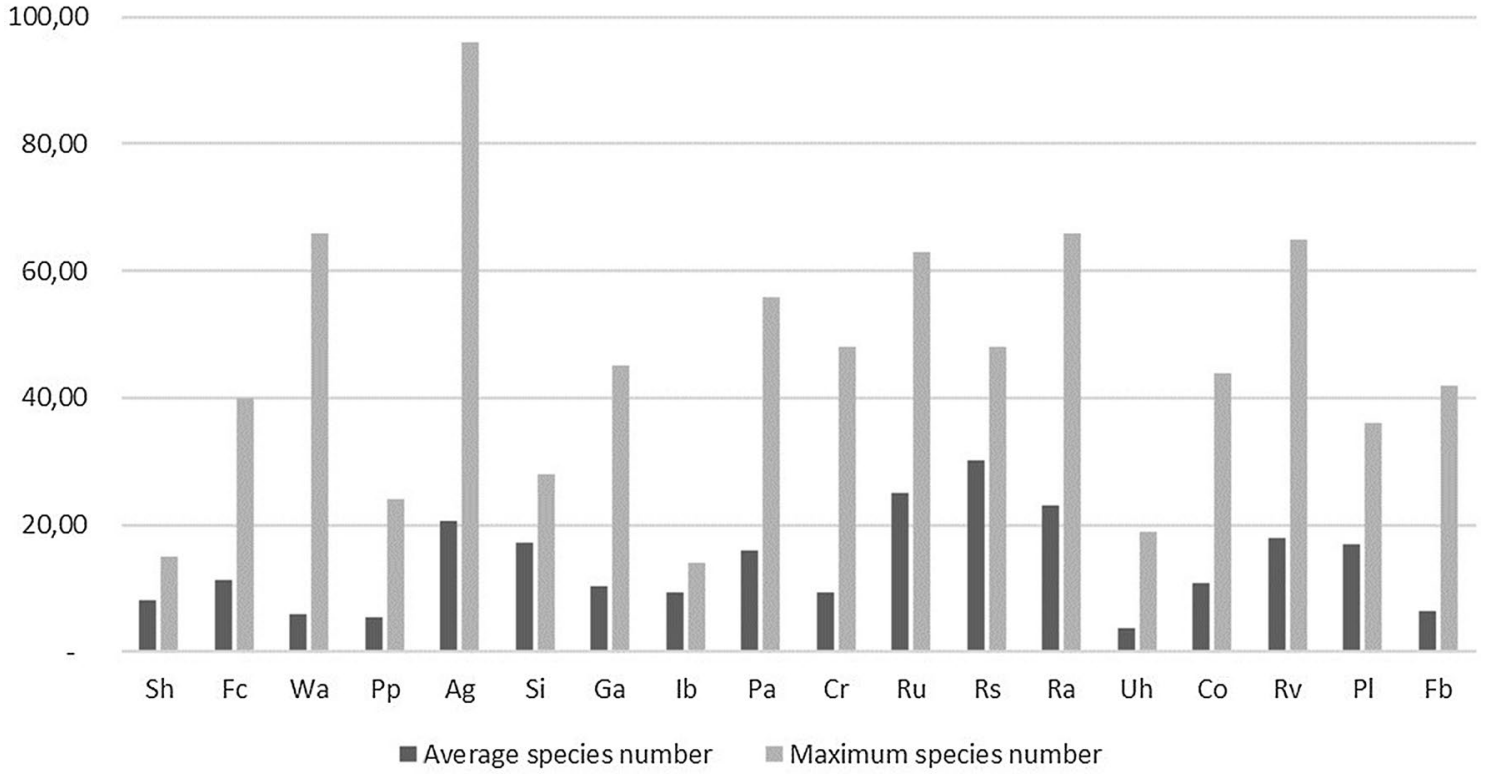

Fig. 3 Average and maximum number of species per habitat

Fig. 4 Ratio of records of alien and native species in the studied habitats

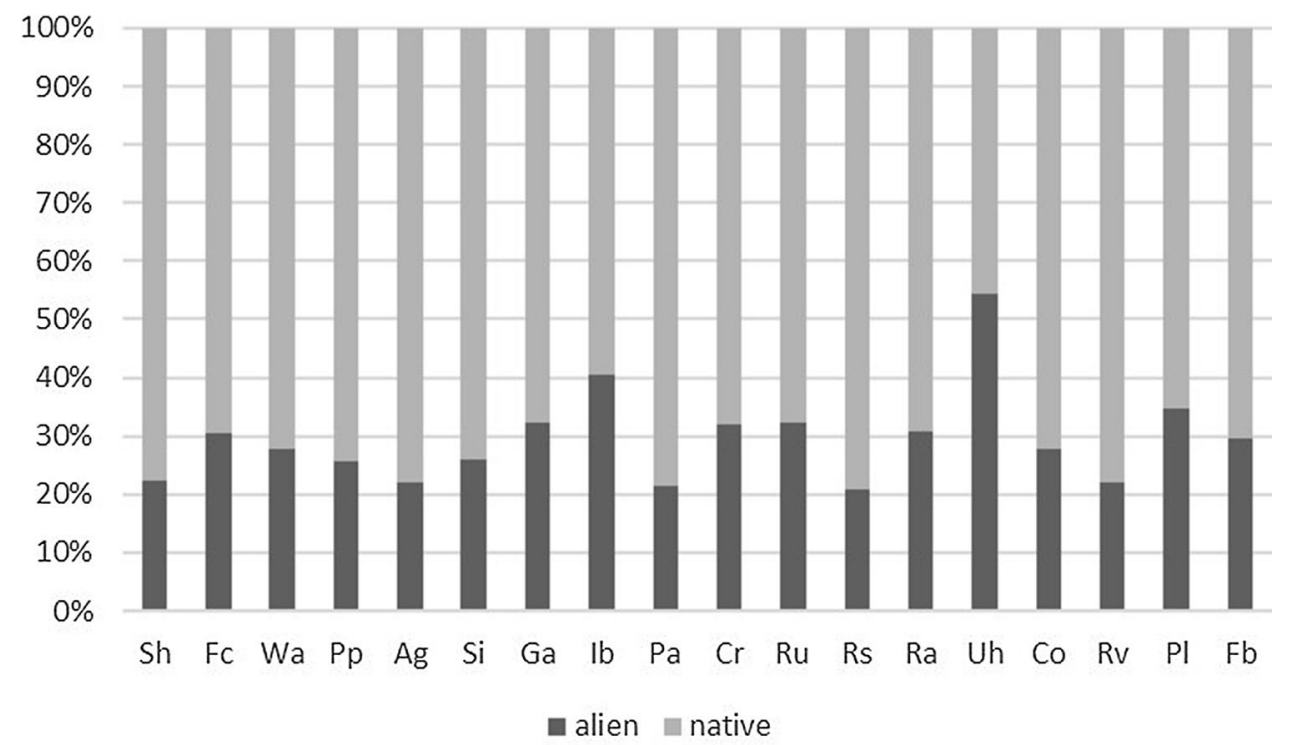

one sixth of them occur sporadically and have one or few records, which support the connections of hosting habitats with species-rich ecosystems (Lundholm and Marlin 2006; Tikka et al. 2001).

The high average number of species in road attached habitats in Budapest confirms the role of roads as corridors, which support the large-scale introduction of alien species (Ascensão and Capinha 2007) and the introduction of natural grassland species at the same time (Tikka et al. 2001). The relative species richness found in unpaved road attached habitats (amenity grasslands and road verges) coincides with the results of Salinitro et al. (2018), who found that habitats with (semi-)natural soils are the most species-rich habitats in the city of Bologna.

The taxa that avoid road attached habitats, occurring mainly in domestic areas, parks and flower boxes in 
Table 3 Spontaneously occurring alien species in Budapest which are missing in the recent Hungarian monographs

\begin{tabular}{|c|c|c|c|c|c|}
\hline Taxon name & $\begin{array}{l}\text { Balogh } \\
\text { et al. } \\
(2004)\end{array}$ & Király (2009) & $\begin{array}{l}\text { Bartha } \\
\text { et al. } \\
(2015)\end{array}$ & $\begin{array}{l}\text { Hungarian } \\
\text { Flora Atlas } \\
\text { (online, 2018-) }\end{array}$ & New occurrences in Budapest \\
\hline Aesculus hippocastanum & + & $!$ & - & + & XII. Béla király út \\
\hline Albizia julibrissin & + & - & - & - & Rigó (2019) \\
\hline Alcea rosea & + & + & - & + & $\begin{array}{l}\text { IV. Temesvári utca, Munkásotthon utca, Bercsényi utca; IX. } \\
\text { Vágóhíd utca; XI. Alíz utca, Laufenauer utca, Töhötöm } \\
\text { utca }\end{array}$ \\
\hline Amaranthus patulus & + & + & - & + & IX. Túzoltó utca; Rigó (2019) \\
\hline Antirrhinum majus & + & + & - & + & IX. Bokréta utca; XI. Bod Péter utca \\
\hline Apium graveolens & - & + & - & + & IX. Bokréta utca \\
\hline Armeniaca vulgaris & - & + & - & + & XI. Budafoki utca \\
\hline Artemisia verlotiorum & - & - & - & - & XI. Budafoki utca \\
\hline Begonia cf. cucullata & - & - & - & - & Rigó (2019) \\
\hline Berberis julianae & + & $!$ & - & + & V. Petőfi utca \\
\hline Brassica rapa & + & + & - & + & $\begin{array}{l}\text { VIII. Fiumei utca, Hungária körút; IX. Gyáli utca, Kvassay } \\
\text { híd, Mester utca, Péceli utca, Rádai utca, Soroksári utca; } \\
\text { X. Kerepesi utca, Kőér utca; XI. Dombóvári utca, Stegova } \\
\text { utca; XII. Karthauzi utca, XIV. Hungária körút, Kerepesi } \\
\text { utca; XXI. Petróleum utca }\end{array}$ \\
\hline Brunnera macrophylla & + & + & - & + & $\begin{array}{l}\text { IV. Lőrinc utca; XI. Bonc utca, Eszék utca, Fadrusz utca, } \\
\text { Kond utca, Laufenauer utca, Szabolcska utca; XII. Strom- } \\
\text { feld utca; XIII. Esztergomi utca }\end{array}$ \\
\hline Buddleja davidii & + & + & - & + & IX. Szent István Kórház, X. Kőér utca; XII. Eötvös utca \\
\hline Buxus sempervirens & + & $!$ & - & + & XI. Baranyai utca \\
\hline Calendula officinalis & + & $!$ & - & + & IX. Liliom utca; XIII. Göncöl utca \\
\hline Campsis radicans & + & $!$ & - & + & $\begin{array}{l}\text { VIII. Győrffy István utca, IX. Gubacsi utca Mester utca, } \\
\text { Péceli utca; XI. Bod Péter utca }\end{array}$ \\
\hline Capsicum аппиит & + & + & - & + & VI. Liszt Ferenc tér; XI. Alíz utca \\
\hline Catalpa bignonioides & + & $!$ & - & + & IX. Berzenczey utca; \\
\hline Celosia argentea & - & $!$ & - & - & IX. Ipar utca \\
\hline Cerastium tomentosum & + & + & - & + & III. Jablonka út \\
\hline Cercis siliquastrum & + & $!$ & - & + & $\begin{array}{l}\text { V. Fôvám tér; VIII. Villám utca; IX. Soroksári utca; XI. Bod } \\
\text { Péter utca; XIII. Váci utca }\end{array}$ \\
\hline Citrullus lanatus & - & $!$ & - & + & $\begin{array}{l}\text { VIII. Orczy utca; IX. Túzoltó utca, Vaskapu utca; X. Kere- } \\
\text { pesi utca; }\end{array}$ \\
\hline Commelina communis & + & + & - & + & $\begin{array}{l}\text { I. Attila utca, II. Csalogány utca, IV. Bercsényi utca, } \\
\text { Munkásotthon utca, Nádor utca; V. Galamb utca, Szemere } \\
\text { utca; VII. Dembinszky utca; VIII. Baross utca, Elnök utca, } \\
\text { József körút, Kerepesi utca, Könyves Kálmán körút, Krúdy } \\
\text { Gyula utca, Mária utca, Szenes Iván tér, Üllői utca; IX. } \\
\text { Angyal utca, Ernő utca, Mester utca, Péceli utca, Ráday } \\
\text { utca, Vágóhíd utca; X. Salgótarjáni út; XI. Baranyai utca, } \\
\text { Bártfai utca, Egry József utca, Eszék utca, Fadrusz utca, } \\
\text { Petzvál József utca, Sopron utca; XIII. Angyalföldi utca, } \\
\text { Dagály utca, Fáy út; Göncöl utca, Váci utca; Tomori Pál } \\
\text { utca, Tutaj utca; XIV. Hungária körút; XX. Fás utca; Rigó } \\
\text { (2019) }\end{array}$ \\
\hline Corylus colurna & + & $!$ & - & + & $\begin{array}{l}\text { III. Bécsi út, Jablonka út; XII. Béla király út, Eötvös utca, } \\
\text { Istenhegyi út }\end{array}$ \\
\hline Cotoneaster horizontalis & + & + & - & + & $\begin{array}{l}\text { I. Gellért tér, Vérmezô út; III. Jablonka utca; VIII. Semmel- } \\
\text { weis University; IX. Mester utca, Nagyvárad tér, Vágóhíd } \\
\text { utca; XI. Alíz utca, Barázda utca, Oroszvég utca }\end{array}$ \\
\hline Cucumis sativus & - & $!$ & - & + & XI. Budafoki út; \\
\hline Datura innoxia & + & + & - & + & VIII. Orczy út; XIII. Vág utca \\
\hline Elymus arenarius & + & + & - & + & III. Jablonka út \\
\hline
\end{tabular}


Table 3 (continued)

\begin{tabular}{|c|c|c|c|c|c|}
\hline Taxon name & $\begin{array}{l}\text { Balogh } \\
\text { et al. } \\
(2004)\end{array}$ & Király (2009) & $\begin{array}{l}\text { Bartha } \\
\text { et al. } \\
(2015)\end{array}$ & $\begin{array}{l}\text { Hungarian } \\
\text { Flora Atlas } \\
\text { (online, 2018-) }\end{array}$ & New occurrences in Budapest \\
\hline Eragrostis virescens & - & - & - & - & IV. Temesvári utca \\
\hline Euonymus japonicus & - & - & - & - & IV. Homoktövis utca \\
\hline Euphorbia lathyris & - & + & - & + & $\begin{array}{l}\text { III. Jablonka út; Kisdomb utca; IX. Péceli utca, Thaly } \\
\text { Kálmán utca; XI. Balogh lejtő, Nándorfejárvári út; XII. } \\
\text { Gyimes utca, Jókai Kert }\end{array}$ \\
\hline Ficus carica & - & $!$ & - & + & IX. Osztag utca; XI. Nándorfejérvári út \\
\hline Gazania rigens & - & - & - & - & IV. Szent István tér \\
\hline Helianthus annuиs & + & + & - & + & $\begin{array}{l}\text { IX. Péceli utca; XXI. Budafoki út, Petróleum utca, Teller Ede } \\
\text { út, Weiss Manfréd utca }\end{array}$ \\
\hline Hibiscus syriacus & + & + & - & + & $\begin{array}{l}\text { I. Vérmező utca; V. Harmincad utca; IV. Munkásotthon utca; } \\
\text { VIII. Bókay utca, Tömő utca; IX. Boráros tér, Drégely utca, } \\
\text { Mester utca; XI. Baranyai utca, Fadrusz utca, Váli utca; } \\
\text { XIII. Szent László tér, Váci út, Vág utca }\end{array}$ \\
\hline Hylotelephium spectabile & + & - & - & - & XIII. Dagály utca \\
\hline Impatiens balsamina & + & $!$ & - & + & XI. Szabolcska Mihály utca \\
\hline Impatiens walleriana & + & $!$ & - & - & VIII. Elnök utca; IX. Angyal utca \\
\hline Ipomoea purpurea & + & + & - & + & $\begin{array}{l}\text { I. Attila út; II. Csalogány utca; VIII. Leonardo da Vinci } \\
\text { utca, Szigony utca; IX. Angyal utca; XI. Fadrusz utca; X. } \\
\text { Salgótarjáni utca; XIII. Röppentyú utca, Tutaj utca }\end{array}$ \\
\hline Lobularia maritima & + & - & - & + & $\begin{array}{l}\text { V. Hold utca; IX. Szemafor utca; XI. Egry József utca; XIII. } \\
\text { Frangepán utca, Váci út; XIV. Hungária körút; Rigó (2019) }\end{array}$ \\
\hline Lonicera japonica & - & + & - & - & X. Üllői út \\
\hline Macleaya cordata & + & - & - & + & Rigó (2019) \\
\hline Maclura pomifera & + & $!$ & - & + & V. Balaton utca; XI. Kond utca \\
\hline Mentha spicata & + & + & - & - & $\begin{array}{l}\text { VIII. Orczy út; IX. Gát sétány, Gizella utca, Márton utca, } \\
\text { Nehru rakpart, Páva utca, Ráday utca; XIII. Tutaj utca }\end{array}$ \\
\hline Mirabilis jalapa & + & $!$ & - & + & XI. Baranyai utca; XII. Felhő utca; Rigó (2019) \\
\hline Miscanthus sinensis & + & - & - & - & XX. Kossuthfalva utca \\
\hline Nepeta $\times$ faasenii & - & - & - & - & IX. Nehru part; Rigó (2019) \\
\hline Perilla frutescens & + & - & - & + & VIII. Kerepesi út \\
\hline Periploca graeca & + & - & - & + & $\begin{array}{l}\text { I. Gellért tér; IX. Gizella utca, Laczkovich utca; XII. Márton- } \\
\text { hegyi út }\end{array}$ \\
\hline Persica vulgaris & - & + & - & + & IV. Szent László út; VIII. Krúdy Gyula utca \\
\hline Petroselinum crispum & + & + & - & + & IX. Ipar utca; XI. Sopron utca \\
\hline Petunia $\times$ atkinsiana & + & + & - & + & $\begin{array}{l}\text { I. Batthyány utca; IV. Kiss Ernő utca; V. Honvéd utca; VIII. } \\
\text { Elnök utca, Mária utca; IX. Dandár utca, Közraktár utca; } \\
\text { Mester utca, Lónyai utca, Ráday utca, Tinódi utca, Üllő́i } \\
\text { út; XI. Bocskai utca, Egry József utca, Eszék utca, Stoczek } \\
\text { utca; XIII. Dagály utca; XIV. Xantus utca; XX. Kossuth- } \\
\text { falva utca, Zalán utca; Rigó (2019) }\end{array}$ \\
\hline Philadelphus coronarius & + & + & - & + & XI. Bártfai utca \\
\hline Platanus hybrida & + & $!$ & - & + & $\begin{array}{l}\text { I. Friedrich Born rkp.; V. Kozma utca, Markó utca, Szabad- } \\
\text { ság tér; VI. Liszt Ferenc tér; VIII. Elnök utca, Múzeum } \\
\text { körút; IX. Gizella utca, Liliom utca, Mester utca, Nehru } \\
\text { part, Túzoltó utca, Üllői út; X. Üllői út, Vajda Péter út; XI. } \\
\text { Alíz utca; XIII. Angyalföldi út, Babér utca, Váci út }\end{array}$ \\
\hline Populus nigra $\mathrm{cv}$. italica & + & $!$ & - & - & XIII. TomoriPál utca; X. Salgótarjáni utca \\
\hline Populus simonii & + & $!$ & - & + & VIII. Krúdy Gyula utca; X. Száva utca; XIII. Dráva utca \\
\hline Pyracantha coccinea & + & - & - & - & IX. Ecseri út \\
\hline Raphanus sativus & - & + & - & + & V. Hold utca; Rigó (2019) \\
\hline Rubus praecox & - & - & - & + & X. Horog utca; IX. Vágóhíd utca \\
\hline Saccharum ravennae & - & - & - & - & IX. Üllői út \\
\hline
\end{tabular}


Table 3 (continued)

\begin{tabular}{|c|c|c|c|c|c|}
\hline Taxon name & $\begin{array}{l}\text { Balogh } \\
\text { et al. } \\
(2004)\end{array}$ & Király (2009) & $\begin{array}{l}\text { Bartha } \\
\text { et al. } \\
(2015)\end{array}$ & $\begin{array}{l}\text { Hungarian } \\
\text { Flora Atlas } \\
\text { (online, 2018-) }\end{array}$ & New occurrences in Budapest \\
\hline Salix babylonica & - & - & - & - & $\begin{array}{l}\text { IX. Drégely utca, Liliom utca, Nehru part; XXI. Weiss } \\
\text { Manfréd utca }\end{array}$ \\
\hline Salvia officinalis & + & - & - & + & XII. Fodor utca \\
\hline Sedum sarmentosum & + & + & - & + & IX. Angyal utca, Páva utca, Ráday utca \\
\hline Setaria italica & - & + & - & + & XI. Rákóczi Bridge \\
\hline Solanum lycopersicon & + & + & - & + & $\begin{array}{l}\text { I. Bem rakpart; II. Csalogány utca; IV. Venetiáner utca; V. } \\
\text { Belgrád rakpart, Bécsi utca, Petőfi utca, Október 6. utca, } \\
\text { Zrínyi Miklós utca; VI. Jókai utca; VII. Dohány utca; VIII. } \\
\text { Harminckettesek tere, Korányi Sándor utca, Leonardo } \\
\text { da Vinci utca, Mária utca, Szigony utca, Tömő utca; IX. } \\
\text { Drégely utca, Gát u, Gubacsi út, Lurdy ház, Ráday utca, } \\
\text { Salkaházy Sára park, Thaly Kálmán utca, Túzoltó utca, } \\
\text { Üllőii út, Vámház körút, Zombori utca; X. Fertő utca, } \\
\text { Kőbányai út; XII. Költő utca; XIII. Angyalföldi út, Kassák } \\
\text { Lajos utca, Váci út, Zsilip utca; XIV. Fogarasi út; XX. } \\
\text { Helsinki út, Zalán utca; XXI. Petróleum utca; Bevásárló } \\
\text { utca, Nagykőrösi út }\end{array}$ \\
\hline Solanum tuberosum & + & $!$ & - & + & IX. Osztag utca, Szerelvény utca \\
\hline Sophora japonica & + & $!$ & - & + & $\begin{array}{l}\text { IV. István út; V. Báthory utca, Falk Miksa utca; VI. Dózsa } \\
\text { György út; IX. Nagyvárad tér, Vágóhíd utca; XIII. Róbert } \\
\text { Károly körút, Mosoly utca }\end{array}$ \\
\hline Symphoricarpos albus & + & $!$ & - & + & IX. Nehru part \\
\hline Tanacetum parthenium & + & + & - & + & $\begin{array}{l}\text { XI. Szabolcska Mihály utca; XI. Október huszonharmadika } \\
\text { utca; Rigó (2019) }\end{array}$ \\
\hline Thuja orientalis & + & + & - & + & XII. Adonis utca; Istenhegyi út \\
\hline Tradescantia virginiana & + & + & - & + & XIII. Tutaj utca; XX. Fás utca \\
\hline Triticum aestivum & - & $!$ & - & + & II. Csalogány utca \\
\hline Tulipa $\times$ gesneriana & + & $!$ & - & - & IX. Márton utca \\
\hline Verbena bonariensis & + & - & - & - & $\begin{array}{l}\text { VIII. Elnök utca, Harminckettesek tere, Mindszenty József } \\
\text { tér }\end{array}$ \\
\hline Viburnum rhitidophyllum & + & $!$ & - & + & VIII. Villám utca; XII. Eötvös út \\
\hline Viola sororia & + & + & - & + & $\begin{array}{l}\text { I. Attila út; IV. Bercsényi utca, Lázár utca; VIII. Tömố utca; } \\
\text { IX. Üllói utca; XIII. Zsilip utca }\end{array}$ \\
\hline Viola $\times$ wittrockiana & + & $!$ & - & - & XIII. Frangepán út \\
\hline Vitex agnus-castus & - & - & - & - & IX. Likőr utca \\
\hline Wisteria sinensis & + & $!$ & - & + & X. Kőér utca; XI. Nándorfejárvári út \\
\hline Zea mays & + & $!$ & - & + & $\begin{array}{l}\text { XIII. Röppentyú utca; XX. Csepeli átjáró; XXI. Petróleum } \\
\text { utca }\end{array}$ \\
\hline Zinnia elegans & + & - & - & + & XIII. Frangepán utca \\
\hline
\end{tabular}

'+' means present, '-'means absent, '!' means listed as an ornamental, Roman numerals represent the districts of Budapest

Budapest, are mainly species of natural wetlands and are unlikely to tolerate permanent disturbance, air pollution, soil contamination and salting. This agrees with Lundholm and Marlin (2006), who found that species of wet natural habitats are less abundant in paved roadsides and more abundant in planted areas.

The high rate of species of natural habitats, especially ferns (Tamás et al. 2017) on built walls is a consequence of the constancy of the ecological conditions experienced, and the appearance of species of wet habitats is a consequence of the specific moisture conditions of the walls (Segal 1969). The frequent presence of the rare and protected marsh fern (Thelypteris palustris) is owing to the presence of abundant natural populations in the adjacent areas along the river Danube (Reszler 1997).

The ten species we found for the first time in Hungary and the 81 we confirmed shows the importance of recent urban floristic research and monitoring. Eight of the new plants are cultivation escapees, which, according to our results are in the early stages of their naturalisation and have a very 


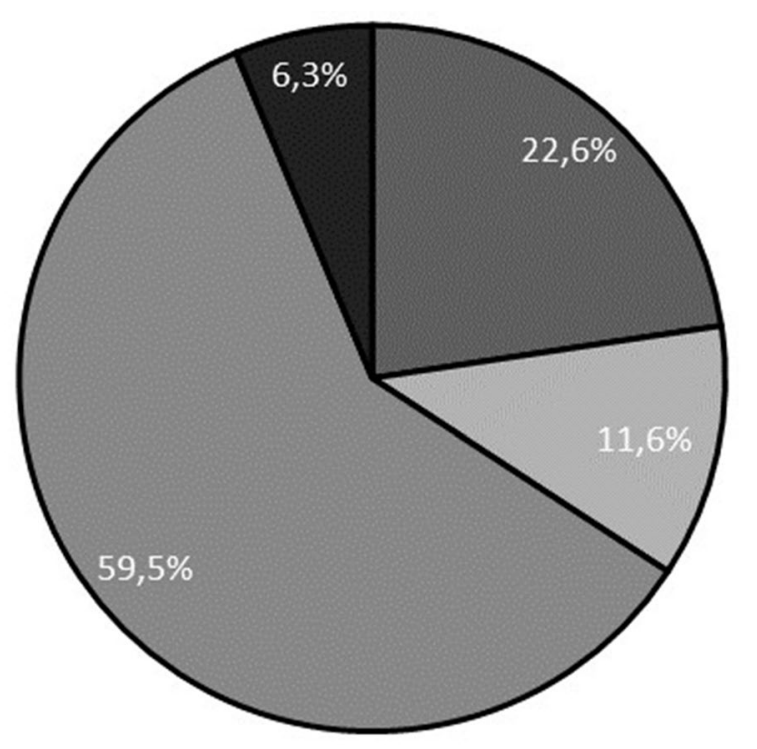

$\boldsymbol{\square}$ invasive $\boldsymbol{\square}$ naturalised $\boldsymbol{\square}$ casual $\boldsymbol{\square}$ introduced

Fig. 5 Status of the alien flora of Budapest

small distribution area in Hungary so far. The high number of cultivated species occurring spontaneously in Budapest is because of the overall presence of gardening in the city, and more than half of the alien taxa are also cultivated in the whole country. Further monitoring of these taxa is very important in the future, as tracking the spread of these species, can yield an enormous amount of information. Though the introduction of alien species is studied worldwide (Hulme et al. 2008; Kowarik et al. 2013), the related terminology is developed for national and larger levels where the way of entry of aliens is relatively well definable and traceable. For cities, it is more difficult to determine whether individuals of a particular species have escaped directly from cultivation or from an already established population, so categories and direct origins are not always traceable (Salinitro et al. 2018). Furthermore, some native species are locally introduced in Budapest as well (e.g. Sedum hispanicum, Amygdalus nana).

The newly recognised Artemisia verlotiorum is naturalised in most European countries (Mosyakin et al. 2019), but was missing from the Hungarian monographs. Due to its resemblance to Artemisia vulgaris, further field investigations and herbarium revisions are needed to determine the distribution of the plant in Hungary. Eragrostis virescens is also missing from Hungarian monographs, but Király et al. (2019) found that the plant has been sporadically present in Hungary ever since 1929 and was misidentified as Eragrostis parviflora (R. Br.) Trin.

Comparing the total flora, much higher values were found for other Central European capitals (Wien: 1476 species,
$51 \%$ of them are aliens, Berlin: 1418 species, $41 \%$ of them are aliens and Warszawa: 1109 species, 31\% of them are aliens) (Pyšek 1998). The number of the species (647) and the ratio of aliens (29.8\%) in Budapest are small compared to these numbers. Pyšek (1998) also found that the number of species correlates with city size and the density of human population. The reasons for the low number of species are that our research was carried out only in autumn, so the plants of spring and summer aspects were not recorded and our research is restricted to anthropogenic habitats of Budapest. Because of this, the 647 plant species found in Budapest are not to be considered small.

\section{Conclusion for Future Biology}

Biological invasions are one of the greatest threats to natural habitats, biodiversity and human health. Halting or mitigating the expansion of invasive plants is the common responsibility of researchers (especially in the field of biology), decision makers, horticultural, economic and industrial actors. On the part of biologists and ecologists this means that future researchers should pay more attention to the understanding of invasion biology. One of the hotspots of biological invasions are urban areas, so one of the main objectives of future biology is to concentrate on the systematic research of urban (and other anthropogenic) habitats to gain a better understanding of invasions from the starting point to the unstoppable expansion of invasive species. Our research serves this need by starting the systematic research of a Central European capital, Budapest, with integrated methods. The development of habitat categories of secondary habitats (such as urban areas) in habitat classification systems is essential if researchers wish to understand the species selection traits of secondary habitats and the preferences of species of secondary habitats. We hope our research contributes to the understanding of the habitat preferences of invasive plants, so the scientific community can provide solutions to one of the greatest challenges of humanity in the near future. We would also like to point out that this research does not only focus on adventive or invasive plants, as it also raises our knowledge on the preferences of many members of the native flora, even protected plant species, so that we can evaluate the role of urban habitats in nature conservation. Finally, we would like to emphasize that we need a better understanding on secondary habitats and the species occurring in them, the surveys should be done on the smaller scale as possible. The secondary habitats are and will be very important in future biology, because of the decrease of (semi-)natural habitats.

Acknowledgements Open access funding provided by Szent István University. We would like to thank András Schmotzer and Kornél 
Table 4 Estimated distance of plants escaped from cultivation from the nearest planted individuals

\begin{tabular}{|c|c|c|}
\hline Species & $\begin{array}{l}\text { Number of records of found } \\
\text { planted (parent) plants }\end{array}$ & $\begin{array}{l}\text { Deviation of the estimated distances } \\
\text { from the nearest planted individuals } \\
\text { (m) }\end{array}$ \\
\hline Albizia julibrissin & 1 & 60 \\
\hline Antirrhinum majus & 1 & 5 \\
\hline Aquilegia vulgaris & 3 & 1 \\
\hline Begonia cf. cucullata & 1 & 20 \\
\hline Broussonetia papyrifera & 7 & $0.5-1$ \\
\hline Brunnera macrophylla & 7 & $0.5-1$ \\
\hline Campanula carpatica & 2 & 1 \\
\hline Campsis radicans & 5 & 1 \\
\hline Catalpa bignonioides & 1 & 8 \\
\hline Cerastium tomentosum & 1 & 0.5 \\
\hline Cercis siliquastrum & 4 & $1-2$ \\
\hline Commelina communis & 6 & $1-30$ \\
\hline Cosmos bipinnatus & 1 & 5 \\
\hline Cotoneaster horizontalis & 2 & $2-3$ \\
\hline Hibiscus syriacus & 9 & $1-2$ \\
\hline Hylotelephium spectabile & 1 & 1 \\
\hline Impatiens walleriana & 1 & 1 \\
\hline Macleaya cordata & 1 & 1 \\
\hline Mirabilis jalapa & 2 & $1-3$ \\
\hline Nepeta $\times$ faasenii & 2 & $5-20$ \\
\hline Petunia $\times$ atkinsiana & 1 & 5 \\
\hline Philadelphus coronarius & 1 & 1 \\
\hline Platanus hybrida & 8 & $1-15$ \\
\hline Populus nigra cv. italica & 1 & 3 \\
\hline Populus simonii & 2 & 30 \\
\hline Portulaca grandiflora & 6 & 1 \\
\hline Pyracantha coccinea & 16 & $0.5-1.5$ \\
\hline Rhus typhina & 2 & $0.5-1$ \\
\hline Salix babylonica & 1 & 20 \\
\hline Sophora japonica & 1 & 3 \\
\hline Tanacetum parthenium & 2 & $0.5-5$ \\
\hline Taxus baccata & 9 & $0.5-2$ \\
\hline Thuja orientalis & 3 & $0.5-3$ \\
\hline Tradescantia virginiana & 1 & 4 \\
\hline Verbena bonariensis & 2 & 0.5 \\
\hline Vinca major & 4 & $0.5-2$ \\
\hline Vitex agnus-castus & 2 & 2 \\
\hline Wisteria sinensis & 1 & 3 \\
\hline
\end{tabular}

Baráth for providing us with valuable advice by revising the manuscript. We would also like to thank Tamás Rigó for the linguistic revision of the manuscript.

Authors' contributions ZB designed the protocol of the research. AR and $\mathrm{ZB}$ gathered the data on field, analysed the data, drafted the article and created figures and tables. AR compiled the literature cited in the article.

Data accessibility The data of our research is still broadening, and therefore not available for the public. Not every data is included in this paper.

\section{Compliance with ethical standards}

Conflict of interest The authors declare no competing interests.

Open Access This article is licensed under a Creative Commons Attribution 4.0 International License, which permits use, sharing, adaptation, distribution and reproduction in any medium or format, as long as you give appropriate credit to the original author(s) and the source, provide a link to the Creative Commons licence, and indicate if changes were made. The images or other third party material in this article are included in the article's Creative Commons licence, unless indicated 
otherwise in a credit line to the material. If material is not included in the article's Creative Commons licence and your intended use is not permitted by statutory regulation or exceeds the permitted use, you will need to obtain permission directly from the copyright holder. To view a copy of this licence, visit http://creativecommons.org/licenses/by/4.0/.

\section{References}

Ascensão F, Capinha C (2007) Aliens on the move: transportation networks and non-native species. In: Borda-de-Água L, Barrientos R, Beja P, Pereira HM (eds) Railway ecology. Springer Publishing Co, Cham, pp 65-80

Balogh L, Dancza I, Király G (2004) A magyarországi neofitonok idôszerú jegyzéke, és besorolásuk inváziós szempontból. In: Mihály B, Botta-Dukát Z (eds) Biológiai inváziók Magyarországon: Özönnövények. TermészetBÚVÁR Alapítvány Kiadó, Budapest, pp 61-92

Bartha D, Király G, Schmidt D, Tiborcz V, Barina Z, Csiky J, Jakab G, Lesku B, Schmotzer A, Vidéki R, Vojtkó A, Zólyomi Sz (eds) (2015) Magyarország edényes növényfajainak elterjedési atlasza. Distribution atlas of vascular plants of Hungary. Nyugat-magyarországi Egyetem Kiadó [University of West Hungary Press], Sopron, p 329

Blackburn TM, Pyšek P, Bacher S, Carlton JT, Duncan RP, Jarošík V, Wilson JRU, Richardson DM (2011) A proposed unified framework for biological invasions. Trends Ecol Evol 26:333-339. https ://doi.org/10.1016/j.tree.2011.03.023

Bölöni J, Molnár Zs, Illyés E, Kun A (2007) A new habitat classification and manual for standardized habitat mapping. Annali di Botanica Nouva Series 7:105-126

Bölöni J, Molnár Zs, Kun A (eds) (2011) Magyarország élőhelyei. A hazai vegetációtípusok leírása és határozója. ÁNÉR 2011. MTA ÖBKI, Vácrátót, p 441

Bourbia F, Boucheriba F (2010) Impact of street design on urban microclimate for semi arid climate (Constantine). Renew Energy 35:343-347. https://doi.org/10.1016/j.renene.2009.07.017

Celesti Grapow L, Blasi C (1998) A comparison of the urban flora of different phytoclimatic regions in Italy. Glob Ecol Biogeo Lett 7:367-378. https://doi.org/10.1046/j.1466-822x.1998.00304.x

Czúcz B (2005) A budai Vár fásszárú adventív flórája. Kitaibelia 10(1):73-87

Early R, Bradley AB, Dukes JS, Lawler JJ, Olden JD, Blumenthal DM, Gonzalez P, Grosholz ED, Ibañez I, Miller LP, Sorte CJB, Tatem $\mathrm{AJ}$ (2016) Global threats from invasive alien species in the twentyfirst century and national response capacities. Nat Comm 7:12485. https://doi.org/10.1038/ncomms12485

Fekete G, Molnár Zs, Horváth F (eds) (1997) A magyarországi élőhelyek leírása, határozója és a Nemzeti Élőhely-osztályozási Rendszer. A Nemzeti Biodiverzitás-monitorozó Rendszer Kézikönyvei II. Természettudományi Múzeum, Budapest, p 298

Horváth A, Szúcs P, Bidló A (2014) Soil condition and pollution in urban soils: evaluation of the soil quality in a Hungarian town. $\mathrm{J}$ Soils Sedim. https://doi.org/10.1007/s11368-014-0991-4

Hulme P, Bacher S, Kenis M, Klotz S, Kühn I, Minchin D, Nentwig W, Olenin S, Panov V, Pergl J, Pyšek P, Roques A, Sol D, Solarz W, Vilà M (2008) Grasping at the routes of biological invasions: a framework for integrating pathways into policy. J Appl Ecol 45:403-414. https://doi.org/10.1111/j.1365-2664.2007.01442.x

Jorquera H, Montoya LD, Rojas NY (2019) Urban air pollution. In: Henríquez C, Romero H (eds) Urban climates in Latin America. Springer, Cham. https://doi.org/10.1007/978-3-319-97013-4_7

Király G (ed) (2009) Új Magyar füvészkönyv. Magyarország hajtásos növényei. Határozókulcsok [New Hungarian Herbal. The Vascular
Plants of Hungary. Identification key]. Aggteleki Nemzeti Park Igazgatóság, Jósvafő, p 616

Király G, Hohla M, Süveges K, Hábenczyus AA, Barina Z, Király A, Lukács BA, Türke IJ, Takács A (2019) Taxonomical and chorological notes 10 (98-110). Stud Bot Hung 50:391-407. https://doi. org/10.17110/StudBot.2019.50.2.391

Kowarik I, von der Lippe M, Cierjacks A (2013) Prevalence of alien versus native species o woody plants in Berlin differs between habitats and at different scales. Preslia 85:113-132

Li G, Sun G-X, Ren Y, Luo XS (2018) Urban soil and human health: a review. Eur J Soil Sci 69:196-215. https://doi.org/10.1111/ ejss. 12518

Lososová Z, Horsák M, Chytry M, Čejka T, Danihelka J, Fajmon K, Hájek O, Jurickova L, Kintrová K, Láníková D, Preislerová Z, Řehořek V, Tichý L (2011) Diversity of Central European urban biota: effects of human-made habitat types on plants and land snails. J Biogeogr 38:1152-1163. https://doi.org/10.111 1/j.1365-2699.2011.02475.x

Lundholm JT, Marlin A (2006) Habitat origins and microhabitat preferences of urban plant species. Urban Ecosys 9:139-159. https:// doi.org/10.1007/s11252-006-8587-4

Maslo S (2014) The urban flora of the city of Mostar (Bosnia and Herzegovina). Nat Croa 23:101-145

Maslo S (2015) Alien flora of the city of Mostar (Bosnia and Herzegovina). Herbologia 15:1-16. https://doi.org/10.5644/herb.15.2.01

Mazza G, Tricarico E, Genovesi P, Gherardi F (2014) Biological invaders are threats to human health: an overview. Ethol Ecol Evol 26:112-129. https://doi.org/10.1080/03949370.2013.863225

McPhearson T, Karki M, Herzog C, Santiago Fink H, Abbadie L, Kremer P, Clark CM, Palmer MI, Perini K (2018) Urban ecosystems and biodiversity. In: Rosenzweig C, Solecki W, Romero-Lankao P, Mehrotra S, Dhakal S, Ali Ibrahim S (eds) Climate change and cities: second assessment report of the urban climate change research network. Cambridge University Press, New York, pp 257-318

Mohajerani A, Bakaric J, Jeffrey-Bailey T (2017) The urban heat island effect, its causes, and mitigation, with reference to the thermal properties of asphalt concrete. J Environ Manag 197:522-538. https://doi.org/10.1016/j.jenvman.2017.03.095

Mosyakin SL, Boiko GV, Glukhova SA (2019) Artemisia verlotiorum (Asteraceae) in the continental part of Ukraine: now in Kyiv. Ukr Bot Jour 76:3-8

Nagy KM, Malatinszky Á (2019) Védett és adventív növények állományfelmérése a budapesti Széchenyi-hegyen. Bot Közl 106:183-196. https://doi.org/10.17716/BotKo zlem.2019.106.2.183

Padayachee AL, Irlich UM, Faulkner KT, Gaertne M, Procheş Ş, Wilson JRU, Rouget M (2017) How do invasive species travel to and through urban environments? Biol Invas 19:1-14. https://doi. org/10.1007/s10530-017-1596-9

Pascal M, Corso M, Chanel O, Declercq C, Badaloni C, Cesaroni G, Henschel S, Meister K, Haluza D, Martin-Olmedo P, Medina S, Aphekom group (2013) Assessing the public health impacts of urban air pollution in 25 European cities: results of the Aphekom project. Sci Total Environ 449:390-400. https://doi.org/10.1016/j. scitotenv.2013.01.077

Pickett STA, Cadenasso ML, Rosi-Marshall EJ, Belt KT, Groffman PM, Grove JM, Irwin EG, Kaushal SS, LaDeau SL, Nilon CH, Swan CM, Warren PS (2017) Dynamic heterogeneity: a framework to promote ecological integration and hypothesis generation in urban systems. Urban Ecosys 20:1-14. https://doi.org/10.1007/ s11252-016-0574-9

Polgár S (1914) Újabb adatok Győr adventivus és ruderális flórájához. Magyar Bot Lapok 13:60-69

Pyšek P (1998) Alien and native species in central european urban floras: a quantitative comparison. J Biogeogr 25:155-163 
Rebele F (1994) Urban ecology and special features of urban ecosystems. Glob Ecol Biogeogr Letters 4:173-187

Reszler G (1997) Hagymaburok (Liparis loeselii (L.) Rich.) a Soroksári-Dunán. Kitaibelia 2:147

Richardson DM, Pyšek P, Rejmánek M, Barbour MG, Panetta FD, West CJ (2000) Naturalisation and invasion of alien plants: concepts and definitions. Diver Distrib 6:93-107

Ricotta C, Godefroid S, Rocchini D (2010) Patterns of native and exotic species richness in the urban flora of Brussels: rejecting the 'rich get richer' model. Biol Invasions 12:233-240. https:// doi.org/10.1007/s10530-009-9445-0

Rigó A (2019) Additions to the Distribution atlas of vascular plants of Hungary. Stud Botan Hung 50:185-224. https://doi.org/10.17110 /StudBot.2019.50.1.185

Rumlerová Z, Vilà M, Pergl J, Nentwig W, Pyšek P (2016) Scoring environmental and socioeconomic impacts of alien plants invasive in Europe. Biol Inv 18:3697-3711. https://doi.org/10.1007/s1053 0-016-1259-2

Salinitro M, Alessandrini A, Zappi A, Melucci D, Tassoni A (2018) Floristic diversity in different urban ecological niches of a southern European city. Sci Rep 8:15110. https://doi.org/10.1038/s4159 8-018-33346-6

Segal S (1969) Ecological notes on wall vegetation. Springer, Berlin, p 325

Simonkai L (1877) Fúvészeti jegyzetek Budapest és környékének növényzetéról. Magyar Növényt Lapok 1:125-128

Stešević D, Caković D, Jovanović S (2014) The Urban Flora of Podgorica (Montenegro, SE Europe): annotated checklist, distribution atlas, habitats and life-forms, taxonomic, phytogeographical and ecological analysis. Ecol Montenegr Suppl 1:1-171
Tamás J, Vida G, Csontos P (2017) Contributions to the fern flora of Hungary with special attention to built walls. Bot Közl 104:235250. https://doi.org/10.17716/BotKozlem.2017.104.2.235

Tikka PM, Högmander H, Koski PS (2001) Road and railway verges serve as dispersal corridors for grassland plants. Landscape Ecol 16:659-666. https://doi.org/10.1023/A:1013120529382

Tóth Z, Papp L (2012) A budai Sas-hegy edényes flórája. In: Kézdy P, Tóth Z (eds) Természetvédelem és kutatás a budai Sas-hegyen. Duna-Ipoly Nemzeti Park Igazgatóság, Budapest, pp 189-224

United Nations, Department of Economic and Social Affairs, Population Division (2019) World Population Prospects. The 2018 Revision. United Nations, New York

University of Sopron [Soproni Egyetem] (2018-) Hungarian Flora Atlas. Online database, Sopron. http://floraatlasz.uni-sopron.hu. Accessed 19 Nov 2019

von der Lippe M, Säumel I, Kowarik I (2005) Cities as drivers for biological invasions - the role of urban climate and traffic. Die Erde; Zeitschr Gesellschaft für Erdkunde zu Berlin 136:123-143

Wirth T, Kovács D, Lengyel A, Sebe K, Csiky J (2013) Flora Atlas of Pécs (South Hungary): database, structure, examples. In: Alegro A, Borsic I (eds) 4th Croatian botanical symposium, book of abstracts. Croatian Botanical Society, Split, p 132

Wirth T, Kovács D, Sebe K, Lengyel A, Csiky J (2018) Sötét diverzitás: magánkertek fajkészletének hatása a flóra becslésére urbán környezetben. In: Czikkelyné Ágh N, Sándor K, Seress G (eds) 1. Urbanizációs Ökológia Konferencia. Pannon Egyetem, Veszprém, p 37 